\title{
Novel SEPSECS Pathogenic Variants Featuring Unusual Phenotype of Complex Movement Disorder With Thin Corpus Callosum
}

\author{
A Case Report
}

Francesco Nicita, MD, PhD, Lorena Travaglini, PhD, Francesco Bombelli, MD, Michele Tosi, MD, Stefano Pro, MD, Enrico Bertini, MD, and Adele D'Amico, MD, PhD

Neurol Genet 2022;8:e661. doi:10.1212/NXG.0000000000000661

\section{Abstract}

\section{Objectives}

To report a novel association between pathogenic variants in the SEPSECS gene and complex movement disorder with thin corpus callosum (TCC).

\section{Methods}

Clinical exome sequencing was performed in an adult patient with a genetically unsolved neurodegenerative disorder. The main clinical, neuroimaging, and genetic data were described.

\section{Results}

The c.865C > T (p.P289S) and c.1297T > C (p.Y433H) missense variants in SEPSECS (NM 016,955.3) were discovered.

\section{Discussion}

This case represents a novel form of early-onset pyramidal syndrome with optic nerve hypoplasia, which slowly evolved to extrapyramidal syndrome featuring dystonia-parkinsonism, associated with TCC, caused by SEPSECS pathogenic variants. This form enlarges the group of the so-called pyramidal-extrapyramidal syndromes, as well as complex hereditary spastic paraparesis with TCC.

\author{
Correspondence \\ Dr. Nicita \\ francesco.nicita@opbg.net
}

\section{MORE ONLINE}

Video

From the Genetics and Rare Diseases Research Division (N.D.F., L.T., M.T., E.B., A.D.A.), Unit of Neuromuscular and Neurodegenerative Disorders, Department of Neurosciences, Bambino Gesù Children's Hospital, IRCCS; Studio Neurologico Laterano (F.B.); and Neurophysiology Unit (S.P.), Department of Neuroscience, Bambino Gesù Children's Hospital, IRCCS, Rome, Italy.

Go to Neurology.org/NG for full disclosures. Funding information is provided at the end of the article. 
Selenoprotein deficiency is caused by mutations in SECISBP2, SEPSECS, and TRU-TCA1-1, which are 3 crucial components of the selenocysteine ( $\mathrm{Sec}$ ) amino acid insertion pathway into at least 25 human selenoproteins. ${ }^{1}$ SEPSECS, located at $4 \mathrm{p} 15.2$, consists of 12 exons and codes for the Sep (Ophosphoserine) tRNA:Sec tRNA synthase, a 501-amino acid protein that catalyzes the last step in the conversion of SeptRNA to Sec-tRNA. We describe a novel phenotype caused by recessive SEPSECS pathogenic variants.

\section{Case Description}

A 48-year-old man, the offspring of nonconsanguineous parents, had a history of normal birth and development in the first year of life. At age 13 months, he manifested head titubation and ocular nystagmus. He started walking independently at age 14 months and manifested toe walking from the age of 2 years. Language developed normally. Investigations performed over years at several Italian centers included routine biochemistry, metabolic screening, neurophysiology tests, and karyotype that were all unremarkable except for selective IgA deficiency. A brain CT performed at age 18 years indicated mild atrophy of frontal lobes. An ophthalmologic examination documented bilateral optic nerve hypoplasia. Given the constellation of his signs, a diagnosis of spastic paraparesis with nystagmus was considered. Over time, his motor abilities slowly worsened, although he was able to complete high school and work as a school assistant until beginning of the Covid-19 pandemic. Brain MRI performed at age 41 years showed mildly increased frontotemporal subarachnoid spaces and thin corpus callosum (TCC) (Figure). At our first neurologic examination at age 48 years (Video 1), he exhibited normal comprehension with mild bradyphrenia. His language was understandable though dysarthric. A rotatory and horizontal subcontinous ocular nystagmus was evident, as well as microcephaly (occipitofrontal circumference $52 \mathrm{~cm}$ ). Bradykinesia and mild dystonic cervical and feet posturing were evident, as well as mild extrapyramidal rigidity at the upper limb. Deep tendon reflexes were abolished at lower limbs. He was able to walk autonomously with mild wide-based and festinating gait. Neurophysiologic studies showed abnormal motor-evoked and visual-evoked potentials. Nerve conduction studies and electroretinogram were normal.

The study was conducted in accordance with the Declaration of Helsinki. The patient signed consent forms for genetic analysis and for data publication.

All procedures followed were in line with the journal's ethics policy, and the subject gave consent to be videoed for publication both in print and online.

\section{Results}

Clinical exome sequencing discovered compound heterozygous c.865C > T (p.P289S) and c.1297T > C (p.Y433H) missense variants in SEPSECS (NM_016955.3). The 2 variants were both absent in controls (i.e., Exome Sequencing Project, 1000 Genomes Project, Exome Aggregation Consortium) (PM2 criteria) and were in trans because they were inherited from heterozygous parents (PM4 criteria). In silico prediction programs supported a deleterious effect on the gene product ( 25 of 25 and 24 of 25 programs on VarSome [varsome.com/] indicate the 2 variants as pathogenic, respectively) (PP3 criteria); in addition, patient's phenotype is highly specific for a disease with a single genetic etiology (PP4 criteria), and missense variants are a common mechanism of disease in SEPSECS-related disorders (PP2 criteria). According to the abovementioned American College of Medical Genetics criteria, ${ }^{2}$ the 2 variants were classified as likely pathogenic $(\mathrm{V})$.

\section{Discussion}

Selenoproteins are involved in several biological processes as antioxidant defense, regulation of gene expression, control of

Figure Brain Magnetic Resonance Imaging, Sagittal T2-Weighted and Axial T2-FLAIR Images, Performed at Age 41 Years

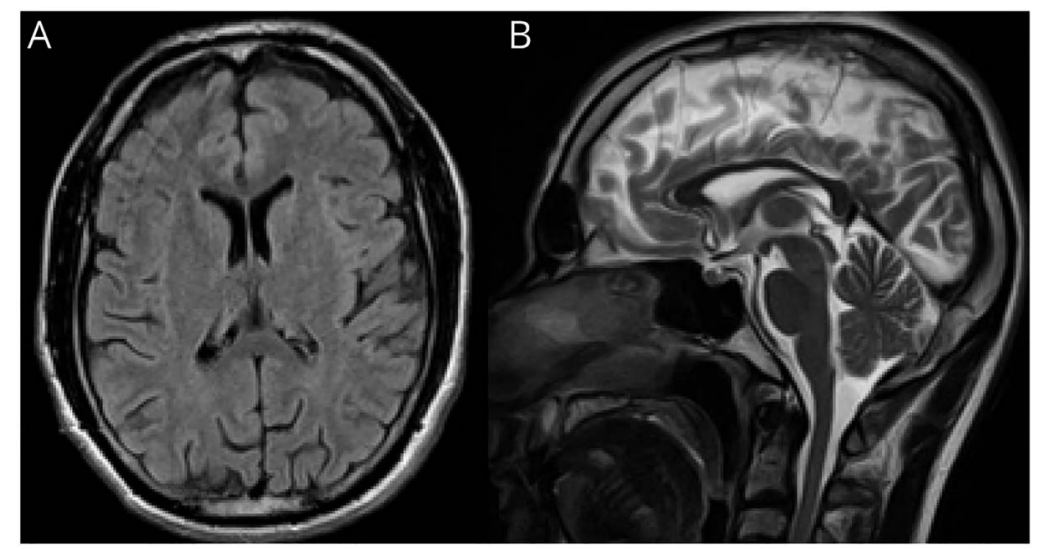

Mildly increased frontotemporal subarachnoid spaces (A) and thin corpus callosum (B), with no basal ganglia (A), white matter (A), cerebellum, and midbrain anomalies (B). 
protein folding, and metabolism of thyroid hormones. ${ }^{1}$ Systemic selenoproteins deficiencies due to SECISBP2 and TRUTCA1-1 recessive pathogenic variants are characterized by multiorgan defects, including abnormal thyroid hormone metabolism, myopathy, hearing loss, and male infertility. ${ }^{1}$ Pathogenic variants in SEPSECS cause pontocerebellar hypoplasia (PCH) type 2D (PCH2D, OMIM \#613811). PCH are rare prenatal-onset neurodegenerative disorders characterized by progressive microcephaly, spasticity, profound mental impairment, and progressive pontocerebellar (and neocortical) atrophy. Dyskinetic movement disorder characterizes the subgroup type 2. PCH2D may span axonal neuropathy, myopathy, epilepsy or epileptic encephalopathy featuring West syndrome, optic nerve hypoplasia, and high blood lactate. ${ }^{3-5}$ In addition, milder neurodegenerative phenotype characterized by earlyonset ataxia with microcephaly and progressive cerebellar atrophy has been described in 3 patients. ${ }^{6,7}$

Our patient had a unique combination of pyramidalextrapyramidal syndrome and optic nerve hypoplasia with TCC without basal ganglia, cerebellum, and midbrain anomalies. Pyramidal features clinically predominated in the first 2 decades, while extrapyramidal symptoms appeared over disease's course in the form of dystonia-parkinsonism with a very slow degenerative course.

Parkinsonian-pyramidal syndromes include neurodegenerative diseases as complex hereditary spastic paraparesis (HSP) (e.g., SPG10, SPG11, SPG15), young-onset parkinsonism, neurodegeneration with brain iron accumulation, primary familial brain calcifications, inborn errors of metabolism (e.g., mitochondrial diseases, Wilson disease, neuronal ceroid lipofuscinosis, manganese transport disorders, Gaucher disease type 3, Niemann-Pick type C, GM1 gangliosidosis type 3$)^{8}$ Most of these conditions have biochemical and/or neuroimaging diagnostic clues, which in our case were limited to TCC, a feature observed in few HSP. Association with optic neuropathy is mainly confined to mitochondrial diseases. In this regard, shared features between mitochondrial and selenoprotein disorders may be related to the role of selenoproteins in the maintenance of redox potential, regulation of redoxsensitive biochemical pathways, and protection from oxidative damage. ${ }^{1}$ Other authors suggested that cells with high mitochondrial activity may be affected by SEPSECS deficiency because mitochondria are one of the main sources of cellular reactive oxygen species. ${ }^{3}$ In conclusion, we describe a patient with early-onset and slowly progressive complex movement disorder caused by novel biallelic SEPSECS pathogenic variants. Our case increases the clinical, mutational, and neuroimaging spectrum of SEPSECS-related phenotypes. An analysis of the few published pathogenic SEPSECS variants indicated that different types of mutations are spread along the gene, thus not clarifying the genotype-phenotype correlations. ${ }^{3-7}$ Reasons for phenotypic variability remain to be explained.

\section{Study Funding}

The authors report no targeted funding.

\section{Disclosure}

The authors report no disclosures relevant to the manuscript. Full disclosure form information provided by the authors is available with the full text of this article at Neurology.org/NG.

\section{Publication History}

Received by Neurology: Genetics October 13, 2021. Accepted in final form January 24, 2022. Submitted and externally peer reviewed. The handling editor was Suman Jayadev, MD.

\section{Appendix Authors}

\begin{tabular}{|c|c|c|}
\hline Name & Location & Contribution \\
\hline $\begin{array}{l}\text { Francesco } \\
\text { Nicita, MD, } \\
\text { PhD }\end{array}$ & $\begin{array}{l}\text { Genetics and Rare Diseases } \\
\text { Research Division, Unit of } \\
\text { Neuromuscular and } \\
\text { Neurodegenerative } \\
\text { Disorders, Department of } \\
\text { Neurosciences, Bambino } \\
\text { Gesù Children's Hospital, } \\
\text { IRCCS, Rome, Italy }\end{array}$ & $\begin{array}{l}\text { Drafting/revision of the article } \\
\text { for content, including medical } \\
\text { writing for content; major role } \\
\text { in the acquisition of data; } \\
\text { study concept or design; and } \\
\text { analysis or interpretation of } \\
\text { data }\end{array}$ \\
\hline $\begin{array}{l}\text { Lorena } \\
\text { Travaglini, } \\
\text { PhD }\end{array}$ & $\begin{array}{l}\text { Genetics and Rare Diseases } \\
\text { Research Division, Unit of } \\
\text { Neuromuscular and } \\
\text { Neurodegenerative } \\
\text { Disorders, Department of } \\
\text { Neurosciences, Bambino } \\
\text { Gesù Children's Hospital, } \\
\text { IRCCS, Rome, Italy }\end{array}$ & $\begin{array}{l}\text { Drafting/revision of the article } \\
\text { for content, including medical } \\
\text { writing for content; study } \\
\text { concept or design; and } \\
\text { analysis or interpretation of } \\
\text { data }\end{array}$ \\
\hline
\end{tabular}

\begin{tabular}{lll}
\hline $\begin{array}{l}\text { Francesco } \\
\text { Bombelli, }\end{array}$ & Studio Neurologico Laterano, & Rome, Italy \\
MD & & $\begin{array}{l}\text { Drafting/revision of the } \\
\text { article for content, including } \\
\text { medical writing for content, } \\
\text { and major role in the } \\
\text { acquisition of data }\end{array}$ \\
\hline
\end{tabular}

Michele Genetics and Rare Diseases Drafting/revision of the article Tosi, MD Research Division, Unit of for content, including medical Neuromuscular and writing for content; study Neurodegenerative concept or design; and Disorders, Department of analysis or interpretation of Neurosciences, Bambino data Gesù Children's Hospital, IRCCS, Rome, Italy

\begin{tabular}{lll}
\hline Stefano & Neurophysiology Unit, & $\begin{array}{l}\text { Drafting/revision of the article } \\
\text { for content, including medical } \\
\text { Pro, MD }\end{array}$ \\
$\begin{array}{ll}\text { Department of Neuroscience, } \\
\text { Bambino Gesù Children's } \\
\text { Hospital, IRCCS, Rome, Italy }\end{array}$ & $\begin{array}{l}\text { writing for content, and } \\
\text { analysis or interpretation of } \\
\text { data }\end{array}$
\end{tabular}

\begin{tabular}{lll}
\hline $\begin{array}{l}\text { Enrico } \\
\text { Bertini, } \\
\text { MD }\end{array}$ & $\begin{array}{l}\text { Genetics and Rare Diseases } \\
\text { Research Division, Unit of } \\
\text { Neuromuscular and } \\
\text { Neurodegenerative } \\
\text { Disorders, Department of } \\
\text { Neurosciences, Bambino } \\
\text { Gesù Children's Hospital, }\end{array}$ & $\begin{array}{l}\text { Drafting/revision of the article } \\
\text { for content, including medical } \\
\text { writing for content; and a } \\
\text { nalysis or interpretation of } \\
\text { data }\end{array}$ \\
& IRCCS, Rome, Italy & \\
\hline Adele & Genetics and Rare Diseases & Drafting/revision of the article \\
D'Amico, & Research Division, Unit of & for content, including medical \\
MD, PhD & Neuromuscular and & $\begin{array}{l}\text { writing for content; major role } \\
\text { in the acquisition of data; } \\
\text { study concept or design; and } \\
\text { analysis or interpretation of } \\
\text { data }\end{array}$ \\
& $\begin{array}{l}\text { Neurodegenerative } \\
\text { Disorders, Department of } \\
\text { Neurosciences, Bambino }\end{array}$ & \\
& $\begin{array}{l}\text { Gesù Children's Hospital, } \\
\text { IRCCS, Rome, Italy }\end{array}$ & \\
& & \\
& &
\end{tabular}

\section{References}

1. Schoenmakers E, Chatterjee K. Human disorders affecting the selenocysteine incorporation pathway cause systemic selenoprotein deficiency. Antioxid Redox Signal 2020;33(7):481-497. 
2. Richards S, Aziz N, Bale S, et al. Standards and guidelines for the interpretation of sequence variants: a joint consensus recommendation of the American College of Medical Genetics and Genomics and the Association for Molecular Pathology. Genet Med 2015;17(5):405-424.

3. Agamy O, Ben Zeev B, Lev D, et al. Mutations disrupting selenocysteine formation cause progressive cerebello-cerebral atrophy. Am J Hum Genet 2010;87(4): 538-544.

4. Anttonen AK, Hilander T, Linnankivi T, et al. Selenoprotein biosynthesis defect causes progressive encephalopathy with elevated lactate. Neurology 2015;85(4): 306-315.
5. Pavlidou E, Salpietro V, Phadke R, et al. Pontocerebellar hypoplasia type 2D and optic nerve atrophy further expand the spectrum associated with selenoprotein biosynthesis deficiency. Eur J Paediatr Neurol 2016;20(3):483-488.

6. Iwama K, Sasaki M, Hirabayashi S, et al. Milder progressive cerebellar atrophy caused by biallelic SEPSECS mutations. J Hum Genet 2016;61(6):527-531.

7. van Dijk T, Vermeij JD, van Koningsbruggen S, Lakeman P, Baas F, Poll-The BT. A SEPSECS mutation in a 23-year-old woman with microcephaly and progressive cerebellar ataxia. J Inherit Metab Dis 2018;41(5):897-898.

8. Tranchant C, Koob M, Anheim M. Parkinsonian-Pyramidal syndromes: a systematic review. Parkinsonism Relat Disord 2017;39:4-16. 


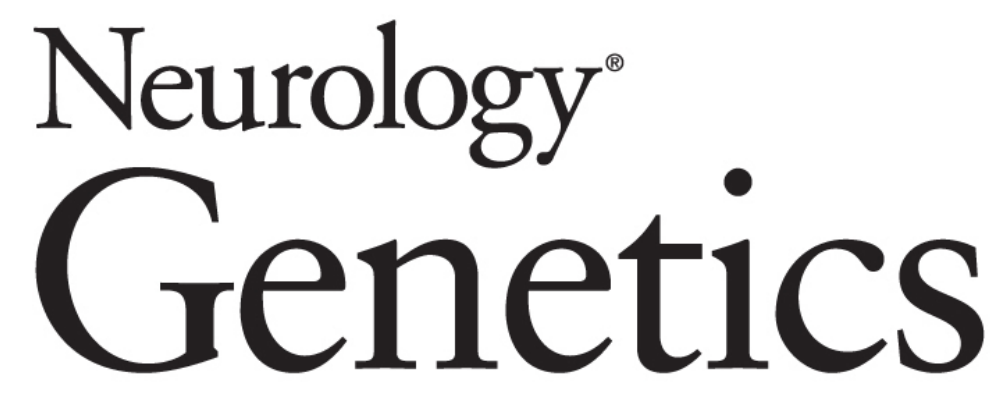
Novel SEPSECS Pathogenic Variants Featuring Unusual Phenotype of Complex Movement Disorder With Thin Corpus Callosum: A Case Report
Francesco Nicita, Lorena Travaglini, Francesco Bombelli, et al. Neurol Genet 2022;8;
DOI 10.1212/NXG.0000000000000661

This information is current as of March 3, 2022

Neurol Genet is an official journal of the American Academy of Neurology. Published since April 2015, it is an open-access, online-only, continuous publication journal. Copyright Copyright $\odot 2022$ The Author(s). Published by Wolters Kluwer Health, Inc. on behalf of the American Academy of Neurology.. All rights reserved. Online ISSN: 2376-7839.

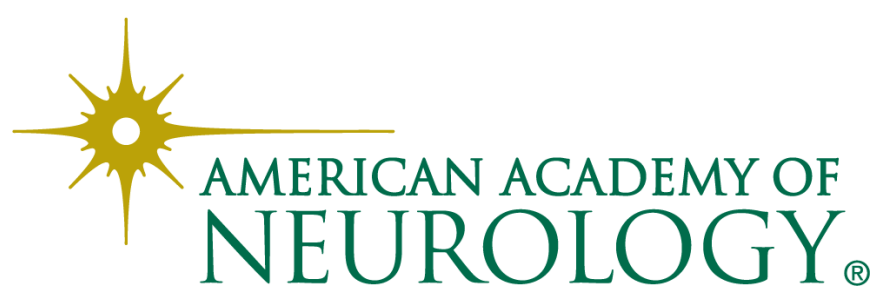




\section{Updated Information \& Services}

References

Subspecialty Collections

Permissions \& Licensing

Reprints including high resolution figures, can be found at:

http://ng.neurology.org/content/8/2/e661.full.html

This article cites 8 articles, 0 of which you can access for free at: http://ng.neurology.org/content/8/2/e661.full.html\#\#ref-list-1

This article, along with others on similar topics, appears in the following collection(s):

\section{Cerebellum}

http://ng.neurology.org//cgi/collection/cerebellum

Dystonia

http://ng.neurology.org//cgi/collection/dystonia

Parkinson's disease/Parkinsonism

http://ng.neurology.org//cgi/collection/parkinsons_disease_parkinsonis $\mathrm{m}$

Spastic paraplegia

http://ng.neurology.org//cgi/collection/spastic_paraplegia

Spinocerebellar ataxia

http://ng.neurology.org//cgi/collection/spinocerebellar_ataxia

Information about reproducing this article in parts (figures,tables) or in its entirety can be found online at:

http://ng.neurology.org/misc/about.xhtml\#permissions

Information about ordering reprints can be found online:

http://ng.neurology.org/misc/addir.xhtml\#reprintsus

Neurol Genet is an official journal of the American Academy of Neurology. Published since April 2015, it is an open-access, online-only, continuous publication journal. Copyright Copyright $\odot 2022$ The Author(s). Published by Wolters Kluwer Health, Inc. on behalf of the American Academy of Neurology.. All rights reserved. Online ISSN: 2376-7839.

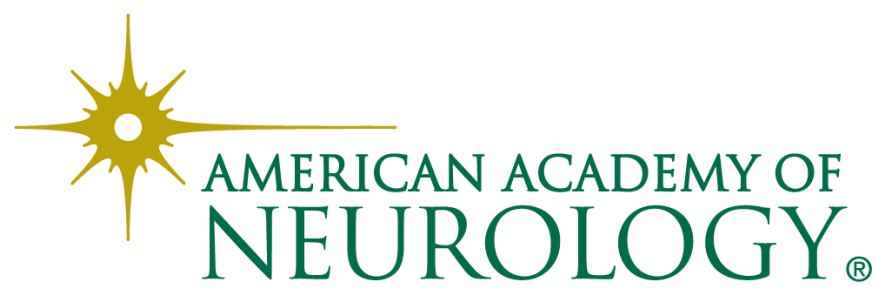

